\title{
LEONARDO DA VINCI'S ANATOMICAL DRAWINGS AND JUAN DE ARFE Y VILLAFAÑE
}

\author{
BORIS RÖHRL \\ University of Applied Sciences RheinMain, Wiesbaden, Germany
}

\begin{abstract}
The four volumes of the Varia commensuración para la escultura y architectura (1585-87) of the Spanish silversmith and sculptor Juan de Arfe y Villafañe represent an extensive compilation of Italian art techniques of the Renaissance. The sources for the Libro segundo, which includes systematic explanations on the theory of proportions, the skeleton and musculature have yet to be discovered. Its didactic and illustrative structure is unique in the context of sixteenth-century literature. The general layout and some details of the illustrations of the first three chapters seem to be derived from the Windsor convolute of anatomical drawings by Leonardo da Vinci.
\end{abstract}

Key words: Anatomical drawings; Artistic anatomy; Leonardo da Vinci; Juan de Arfe y Villafañe; Didactic literature of the Renaissance.

\section{DIBUJOS ANATÓMICOS DE LEONARDO DA VINCI Y JUAN DE ARFE Y VILLAFAÑE}

Los cuatros libros de Varia commensuración para la escultura y architectura (1585-1587) del platero y escultor Juan de Arfe y Villafañe representan un extenso compendio de las teorías y técnicas del Renacimiento italiano. Las fuentes del Libro segundo, que contiene explicaciones sistemáticas sobre la proporción de la figura humana, el esqueleto y la musculatura, aún no han sido descubiertas. La estructura didáctica y las ilustraciones son únicas en el contexto de la literatura del siglo XVI. El formato general y algunos detalles de las ilustraciones de los primeros tres capítulos parecen tener su origen en los dibujos anatómicos de Leonardo da Vinci conservados en el castillo de Windsor.

Palabras clave: Dibujos anatómicos; Anatomía artística; Leonardo da Vinci; Juan Arfe y Villafañe; Literatura didáctica del Renacimiento.

In the late sixteenth century, one of the most advanced manuals on art didactics in Europe was the Varia commensuración para la Esculptura y Architectura (1585-1587) by the Spanish silver and goldsmith, artisan and sculptor Juan de Arfe y Villafañe ${ }^{1}$. The Varia is divided into four books. The first book deals with geometry ${ }^{2}$, whereas the second explains the proportions and

\footnotetext{
1 Arpe y Villafane, 1585, 1587.

${ }^{2}$ Libro primero, trata de las figuras Geometricas y cuerpos regulares è irregulares, con los cortes de sus laminas [...] 1585 .
} 
the anatomy of the human body ${ }^{3}$. The third book shows the drawing of animals ${ }^{4}$ and the fourth is devoted to architecture .

The sources of these four books are sometimes indicated by Arfe himself, but sometimes art historical research of recent decades has uncovered the sources ${ }^{6}$. This article deals especially with the sources of the illustrations in Libro segundo, the book on human proportions and anatomy.

Some of the patters of Arfe's illustrations of Libro segundo are known today: the Vier Bücher von menschlicher Proportion ${ }^{7}$ (1528) by Albrecht Dürer ${ }^{8}$ and Historia de la composición del cuerpo humano (1556) by Juan Valverde de Hamusco9. The manual by Valverde contains modified and changed copies of De humani corporis fabrica (1543) by Andreas Vesalius ${ }^{10}$. Arfe did not use the original illustrations of the Fabrica, but rather those of the Spanish anatomy book by Valverde, since he copied certain details of the illustrations which are only visible in this manual.

The illustrations of Arfe's Libro segundo only show slight similarities to European anatomical book illustrations of the sixteenth and seventeenth centuries. Surely, there are similarities to some book illustrations by Dürer and Valverde ${ }^{11}$. With Arfe, a line of tradition in teaching anatomy for artists was established which has no counterpart in other European countries ${ }^{12}$.

How could he create such splendid illustrations? Arfe was not an anatomical draftsman of the first order. As he indicates in his book, he attended anatomical lessons with Doctor Cosme de Medina of the University of Salamanca ${ }^{13}$. Yet, in his artistic work, we do not see Arfe as an artist who constructed the figure according to rules of deepened knowledge of human anatomy. In light of this, it does not seem likely that he invented all the anatomical illustrations of Libro segundo by himself. The known sources, Dürer and Valverde, will be described in the following article. However, regarding some illustrations of the skeleton and the musculature, no similar book illustrations can be found, neither in medical nor in art didactical literature. Furthermore, we have no preparatory drawings regarding Libro segundo.

There are indications that a third source of images is the convolute of anatomical drawings by Leonardo da Vinci (the former Pompeo Leoni-Volume), now stored at Windsor Castle. Some sheets show a striking similarity to the illustrations in the manual by Arfe. However, it is generally accepted in art history that there were no direct copies of Leonardo's sketches in book print during the sixteenth century. On the other hand, there are indications that these drawings were used as models for Libro segundo.

The first and most significant path which leads from Leonardo to Arfe is the idea of anatomical knowledge especially conceived for sculptors and painters. This idea, which was new and unusual in the fifteenth century, was promoted by Leonardo in his writings on anatomy. We must realise that Libro segundo by Arfe was the first art didactical manual which contained anatomical illustrations especially conceived for the teaching of artists. Libro segundo is the first

\footnotetext{
${ }^{3}$ Libro segundo, trata de la proporcion y medida particular de los miembros del cuerpo humano, con sus huesos y músculos, y los escorzos de sus partes, 1585.

${ }^{4}$ Libro tercero, trata de las alturas formas de los animales y aves, 1587.

${ }^{5}$ Libro quarto, trata de arquitectura y piezas de iglesia [...] 1587.

${ }^{6}$ Arfe refers mainly to Italian sources, for instance in his Libro quarto he used illustrations and texts copied from the treatise of architecture by Sebastiano Serlio. Heredia Moreno, 2003.

7 DÜRER, 1528.

8 Heredia Moreno, 2005, El arte foráneo: 314-317; [On the Four Books see:] HinZ, 2011.

9 VALVERDE, 1556.

10 Vesalius, 1543

11 Heredia Moreno, 2005, El arte foráneo: 309-310.

12 Cortes, 1994: 146-211; Röhrl, 2000: 82-100; Crespo, 2001: 161-171; Garcia Lopez, 2001: 247-264.

13 Arfe y Villafane, 1585: Lib. 2, fol. 25v.
} 
book on artistic anatomy which appeared in printed form. The idea of a specialised monograph on artistic anatomy did not gain wider acceptance before the seventeenth century. During the sixteenth century, there were only two printed treatises for artists which contained chapters on artistic anatomy: Libro segundo (1585) by Arfe and Livre de pourtraiture (1595) by Jean Cousin ${ }^{14}$. From 1600 until 1670, only three printed manuals on artistic anatomy appeared, those by Jacob van der Gracht (1634), François Tortebat (1667) and Bonavera (1670). Apart from these books, model drawings (the main didactical aid), anatomical images in drawing books and anatomical single-leaf prints were used by artists. All early books on artistic anatomy, with the exception of the manual by Arfe, include copies of illustrations from Fabrica by Vesalius. Arfe's Libro segundo is the only one that represents a strong alternative conception of art didactics.

\section{Models of the first chapter on proportion and the fourth chapter on foreshortenings}

The manner of presenting didactics of the Varia is closely connected with Renaissance thought and its preference for mathematical and logical presentation of subject matters. Libro segundo is based of a logical succession on the following four subject matters:

1. Proportions of the human body; 2. The skeleton; 3. The musculature; 4. Foreshortenings of the human limbs.

Parts 1-3 are, again, divided into five main subject matters: 1 . The head is explained from four sides; 2 . The trunk is exposed from four sides; 3 . The upper extremities (arm and hand) are shown from four sides; 4 . The lower extremities (leg and foot) are rendered from four sides; 5. The whole body is displayed from two sides.

The outlines and size of all illustrations in parts 1-3 match each other exactly (compare figs. 1 $\& 2$ ). This means that the stances of the figures are always identical. The presentation of the proportions, bones and muscles of the human limbs is shown exactly from four sides, as in architectural drawing.

Since Arfe was a sculptor and artisan, the chapter on proportions is the most essential in the entire Libro segundo. This chapter provides the general layout for the whole book: the segments of the body, which is shown (figs. $1 \& 3$ ), the outlines of figures and, as a logical consequence, the stiff position of the limbs in this chapter are repeated in the illustrations in the following two subchapters on the skeleton and superficial musculature.

The use of the word "proportions" in Arfe's language is not the same as in contemporary semantics. The meanings of this term also included the teaching of the bone and musculature structure. An interesting point regarding Arfe's second book is presented by his explanations regarding the history of the teaching of proportions for artists. He mentions the Greeks as the creators of the rules of proportions and quickly changes to Pomponius Gauricus ${ }^{15}$ and Albrecht Dürer as their modern successors. Furthermore, he counts Antonio Pollaiuolo, Baccio Bandinelli, Raphael, Andrea Mantegna, Donatello and Michelanglo as those whose merit has been to awaken the rules of human body proportions of classical antiquity again ${ }^{16}$.

Arfe, who was well versed in the history of the didactics on figure drawing, mentions three artists who were not involved in transmitting rules on proportions, but who did attend dissections

\footnotetext{
14 Cousin (Jeune), [1595].

15 Gauricus, 1503.

16 ARfe Y Villafane, 1585: Lib. 2, fol. 2r.
} 
MEDIDA DEL CVERPO TIT. I. 7

3

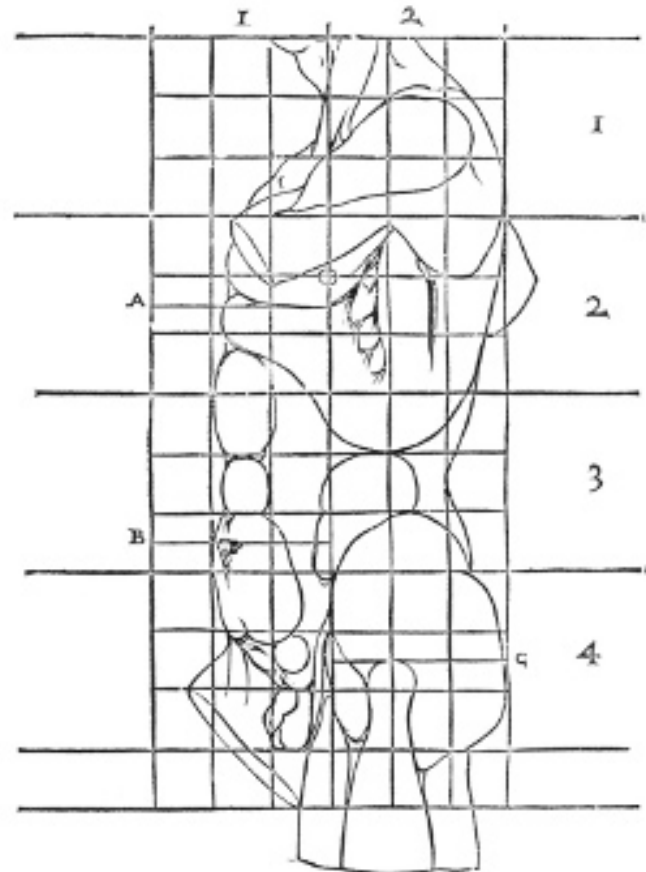

Fig. 1. Juan de Arfe, Proportions of the male torso, in profile to left, from Varia commensuración, 1585, lead print, $27 \times 19.5 \mathrm{~cm}$, Johann-Wolfgang-Goethe University, Library, Frankfurt on Main, Q 15/39.
MORZILLOS DEL CVERPO TIT. IIL 31

3

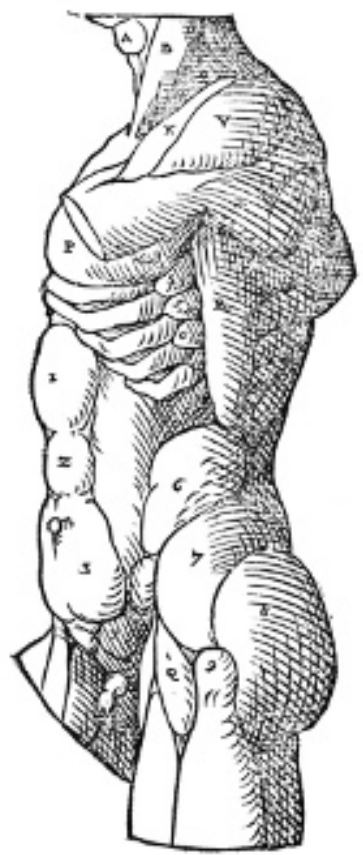

Fig. 2. Juan de Arfe, Superficial musculature of the male torso, profile to left, from Varia commensuración, 1585, lead print, $27 \times 19.5 \mathrm{~cm}$, Johann-Wolfgang-Goethe University, Library, Frankfurt on Main, Q 15/39.

(or indeed dissected themselves): Antonio Pollaiulo ${ }^{17}$, Bandinelli ${ }^{18}$ and Michelangelo. A surprising point is that he did not refer to Leonardo da Vinci. Arfe's historical introduction testifies that he was well acquainted with the evolution of Italian art, but there must have been a reason that he did not mention the greatest anatomist of all, Leonardo da Vinci.

If we compare, for instance, Leonardo's drawing of the male torso from the side in RL 19032v (fig. 4) with a presumable mirror image of the same matter in fol. $7 \mathrm{r}$ (fig. 1), the outlines of the trunk and the idea that the image ends in the region of the throat with a little segment of the jawbone, are the same. However, the rough and partially anatomically inaccurate division of the torso's musculature in the illustration by Arfe in fol. 31r (fig. 2) is different to Leonardo's drawing, which displays a well-understood rendering of the muscles in RL 19032v (fig. 4) and RL

17 Through Vasari's suggestions in the biography of Antonio Pollaiuolo, he became known as the first to embark upon anatomical studies of the human body. He could also have been influenced by Antique sculpture. KoRNELL, 1993: $28 \mathrm{ff}$.

18 KoRNELl, 1993: $138 \mathrm{ff}$. 
$19014 \mathrm{v}$. There are further differences: the position of the arm is changed in Arfe's fols. $7 \mathrm{r}$ and $32 \mathrm{r}$ and these pictures are supplemented with segments of the lower extremities to make the torso more aesthetic. However, in RL 19014v the arm and the upper part of the leg are in the same position as in fols. $7 \mathrm{r}$ and $32 \mathrm{r}$.

Some of the illustration on proportions displays similarities to the Vier Bücher by Dürer, too. The proportions of the face in Arfe's fol. [4] r corresponds with Book 2, fols. G5r and G5v by Dürer. The proportions of the arms in Arfe's fols. 9r [left side] and 9v [left side] is similar to Book 1, fol. B4r (right figure and figure in the centre). Fols. 13r and 13v by Arfe display the proportions of the whole body. Possible patterns are Dürer's Book 2, fols. G5r and G5v.

However, we have to recognise that Dürer is not the source of many of the illustrations in the first chapter: for example, Dürer's Book 1, fol. B4r shows a possible inspiration of Arfe's fol. 7r (fig. 1), but the outlines are completely different. Dürer only presented the outward appearance of the body without any anatomical subdivision. This is not the case in the images by Arfe, whose outlines and anatomical rendering seem to be derived directly from Leonardo's drawings. The distribution of light and shade and the display of main muscles is similar (figs. $2 \& 4$ ). Other resemblances between Arfe and Leonardo exist regarding the proportions of the face. If the proportions of the face, in profile to the left, in the second book on page [4]v (fig. 3) is compared with a study by Leonardo in RL $12601^{19}$ (fig. 5), the diagram by Arfe shows a similar appearance.

During the Renaissance age the division of the face into three equal parts was a common rule $^{20}$. Arfe's diagram has a similar form and also shows the division into three equal parts from the hairline to the chin. However, both diagrams differ in certain details. Leonardo's drawing is much subtler than that by Arfe, whose icon exposes a fourth length beginning from the hairline to the top of the upper outline of the skull. This is a possible interpretation of the face proportions.

There are similarities between these two images, but one has to remember that the transmission of the rules on proportions and their diagrams had been relatively precise and meticulous in former epochs. Therefore, it is possible to interpret these similarities as purely coincidental. However, in fol. [4]v (fig. 3) some details of Arfe's illustration are close to Leonardo's drawing, for instance the round form of the chin and the form of the nose.

If we analyse Leonardo's anatomical study sheets stored at Windsor Castle, there are further similarities. For instance, a detail of sheet RL 19044r (fig. 6) is reflected in Arfe's illustration of the rear view of the trunk in fol. 30v (fig. 7); sheet RL 19032r with the rendering of the musculature of the trunk in front view seems to have served as a pattern for Arfe's fols. 6r (proportions of the trunk, front view) and 30r (musculature of the trunk, front view). One of Leonardo's studies of the lower extremity, RL 12632r (fig. 8) could have served as a pattern for fol. 36v (fig. 9).

It would be excessive to count all the similarities between Leonardo's anatomical drawings and the illustrations on proportions by Arfe. If we assume that there are occasional examples of concordance between anatomical drawings by different artists, the high number of similarities alone testifies that these were not purely by chance.

However, there are no traces of Leonardo's anatomical studies in Arfe's fourth subchapter on foreshortenings: here Dürer seems to be the only source. Copies of illustrations from the Vier Bücher are to be found in Arfe's fol. 42v (Dürer's Book 4, fol. Y3v), fol. 44r (Dürer's Book 1, fol. F1r; Book 4, fol. Y4r), fol. 44v (Dürer's Book 4, fol. V3v), fol. 45r (Dürer's Book 4, fol. V4r), fol. 46r (Dürer's Book 4, fol. V4v), fol. 46v (Dürer's Book 4, fol. X1v).

\footnotetext{
19 Another similar sheet in the Academia in Venice, Inv. 236v. There are at least five different versions of this diagram by Leonardo or anonymous artists.

20 The method to divide the length of the face into three equal parts was already a common rule, with many variants, in Antiquity and was known in the Middle Ages, for instance in the Album de Villard de Honnecourt (ms. fr. 19093, Bibliothèque Nationale de France, Paris).
}

Arch. esp. arte, LXXXVII, 346, ABRIL-JUNIO 2014, 139-156

ISSN: 0004-0428, eISSN: 1988-8511, doi: 10.3989/aearte.2014.10 

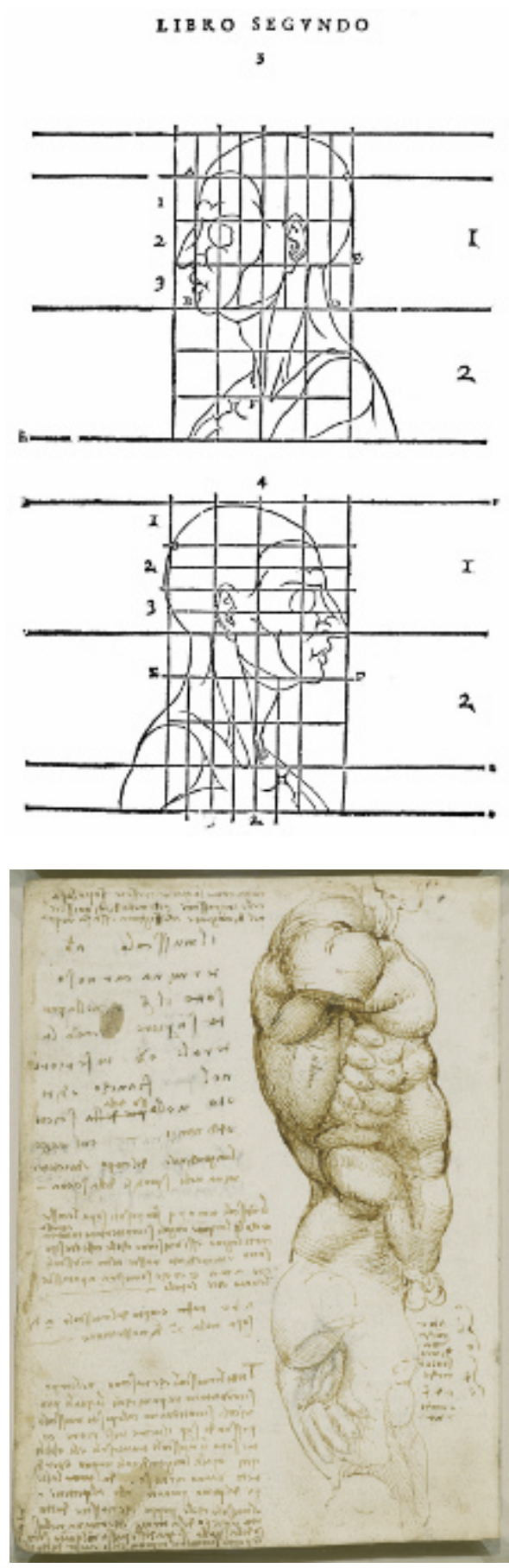

Fig. 4. Leonardo da Vinci, Two drawings of the torso of a man, in profile to right showing superficial muscles, pen and ink, $19.3 \times 14 \mathrm{~cm}$, Windsor Castle, Royal Library, RL 19032v

(C) The Royal Collection, HM Queen Elizabeth II.
Fig. 3. Juan de Arfe, Proportions of the human head, profile to left and right, from Varia commensuración, 1585, lead print, size of the illustration: ca. $11 \times 14 \mathrm{~cm}$, Johann-Wolfgang-Goethe University, Library, Frankfurt on Main, Q 15/39.

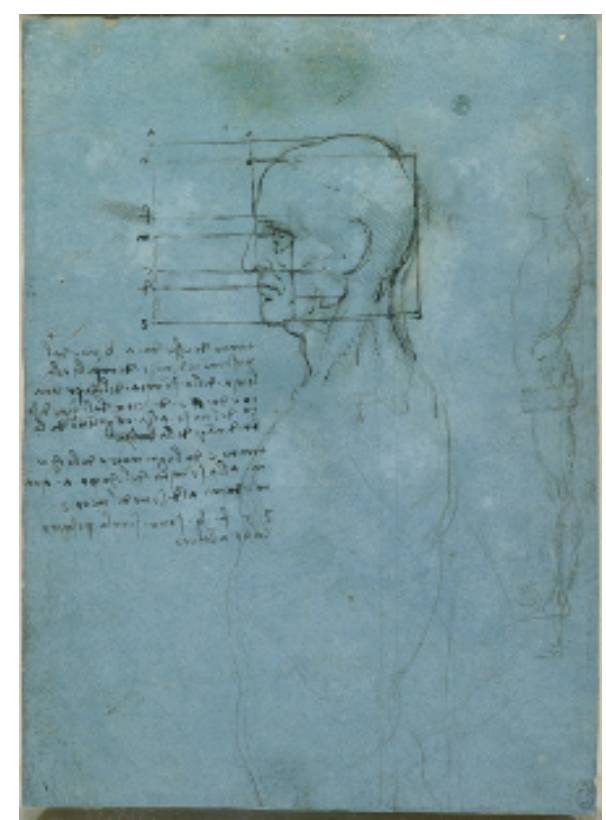

Fig. 5. Leonardo da Vinci, A nude man seen down below the waist, in profile to left, silver point, ink over the measured head, on blue paper, $21.3 \times 15.3$ cm, Windsor Castle, Royal Library, RL 12601r (C) The Royal Collection, HM Queen Elizabeth II.

Arch. esp. arte, LXXXVII, 346, ABRIL-JUNIO 2014, 139-156 ISSN: 0004-0428, eISSN: 1988-8511, doi: 10.3989/aearte.2014.10 


\section{Models of the illustrations of the chapter on the skeleton}

Depictions of the skeleton have a long tradition, already visible in the medieval triumph of death and tomb sculpture ${ }^{21}$. Even in the Middle Ages, Italian sculptors had advanced knowledge of the bone structure of the body ${ }^{22}$. There are two sources for Arfe's illustrations: Valverde's manual of 1556 and Leonardo.

If Leonardo's drawings are compared with Arfe's illustrations regarding osteology and myology, certain similarities can be noted. A study by Leonardo, RL 19012r, depicts the thorax directly from the front, side and back (fig. 10). At the bottom right-hand corner of this sheet there are drawings of the pelvis and the skeleton of the legs, drawn directly from the front and side. In contrast to this, in medical anatomies of the sixteenth century the skeleton was presented in a life-like position.

It is obvious that the visualisation of parts of the skeleton by Arfe follows the same layout as that invented by Leonardo. For instance, Arfe's illustrations of the skeleton of the thorax and pelvis are rendered from the direct front view in fol. 18r (fig. 11), from the back in fol. $18 \mathrm{v}$, and from the left and right-hand sides in vols. $19 \mathrm{r}$ and $19 \mathrm{v}$. Some details seem to have been copied directly from Leonardo's studies. One should compare the long, stretched cervical vertebrae of the neck in RL 19012r (fig. 10, lower left-hand side) and page 18r (fig. 11). The cervical vertebrae are stretched vertically. Fol. 18r with the thorax also shows similarities to Tabla 1 of the first book by Valverde. But here, the cervical vertebrae and the pelvis are in a shifted position to the thorax. Many details of the skeleton in front view depicted in the Historia of 1556 are different to the images contained in Libro segundo. There are, however, important exceptions: for instance, the left foot of the skeleton in Tabla 1, first book, by Valverde, concurs with Arfe's fol. 23r.; the lower part the rib cage of Tabla 1 is reminiscent to Arfe's fol. 18r. This means that Arfe had was aquainted with two sources: Leonardo and Valverde.

Arfe copied anatomical details of Leonardo's drawings, whose visualisation was not common in anatomical medical illustration of the late sixteenth century. Leonardo's studies still depict a simplified anatomy which corresponds to the teaching of anatomy at universities during his epoch. For instance, the forms of the five large vertebrae of the lumbar region are nearly identical in RL 19012r (fig. 10, lower left-hand side). This is too simplified a form of rendering the different vertebrae, which was not displayed in medical anatomical illustration from the mid-sixteenth century onwards. However, this simplified form of depiction is present in Arfe's illustrations of the spine on page 18r (fig. 11).

In his illustrations, Leonardo exposes the connection of the head of the humerus with the joints of the shoulder, the scapula and the clavicle. The same division is displayed in illustrations by Arfe. The anatomical parts added to complete the illustrations by Arfe are obviously copied from the Historia by Valverde. However, several details in the skeletal torso by Arfe are unique and seem to be based on rendering from nature. For instance, the pelvis on page 18r (fig. 11) is in a different position to the pelvis in the centre of Leonardo's RL 19012r (fig. 10). Equally, the front view in the plate does not correspond to the skeleton in front view in the manual by Valverde (or the book by Vesalius), where the male pelvis is shown at another angle. This does not concur with the image of the pelvis in Arfe's fols. 18r (fig. 11), 18v, 19r and 19v.

${ }^{21}$ A modern rendering of the skeleton is already visible in the Triumph of Death in the Camposanto, Pisa, and later in Masaccio's Trinity fresco in Santa Maria Novella, Florence. The evolution of rendering and sculpting the skeleton was, however, unequal, since only painters and sculptors with great skill could manage to display the skeleton or parts of it naturalistically.

22 KoRNELL, 1993: 94-115.

Arch. esp. arte, LXXXVII, 346, ABRIL-JUNIO 2014, 139-156

ISSN: 0004-0428, eISSN: 1988-8511, doi: 10.3989/aearte.2014.10 


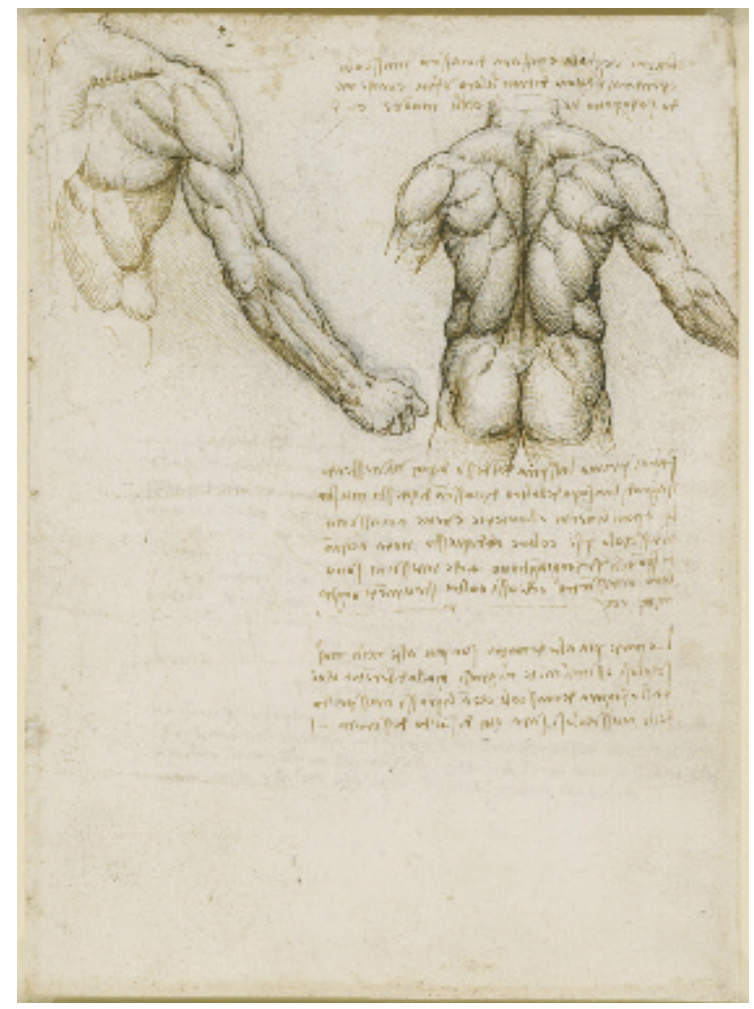

Fig. 6. Leonardo da Vinci, Study of a torso of a man, seen from behind; to left: right half of the body and right arm indicated, pen and ink, $18.9 \times 13.7 \mathrm{~cm}$. Windsor Castle, Royal Library, RL 19044r (C) The Royal Collection, HM Queen Elizabeth II.

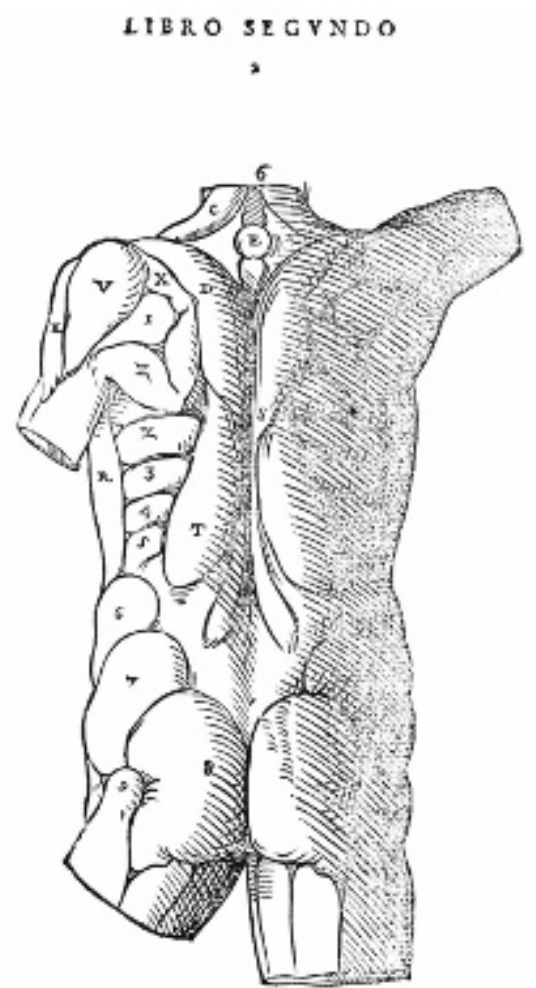

Fig. 7. Juan de Arfe, Superficial musculature of the male torso, seen from behind, from Varia commensuración, 1585, lead print, $27 \times 19.5$ $\mathrm{cm}$, Johann-Wolfgang-Goethe University Library, Frankfurt on Main, Q 15/39.

The general layout of Arfe's subchapter on osteology shows similarities to sketches by Leonardo. Yet, many details of Leonardo's drawings do not find their exact reflection in the osteological illustrations by Arfe, others were copied from Valverde. As in the subchapter on proportions, many elements are depicted in a misleading, partly inaccurate manner. There can be no doubt that Arfe was forced to render supplementary parts. For instance, he had to supplement the left-hand side of Leonardo's drawing of the rib cage and the pelvis of RL 19012r (fig. 10, lower left-hand side). In fol. 18r (fig. 11) Arfe had to change the position of limbs due to the general visual conception of his book.

Further differences and similarities between Arfe's second subchapter of osteology and Leonardo's sketches are: fol. [21]r with the skeleton of the arm and hand in front and back view have no direct counterparts in the Windsor convolute; Arfe's fol. [21]v displays the bone structure of the arm and hand seen from the outer side and inner side. The arm skeleton in the outer side view is a mirror-image of a drawing by Leonardo of the same subject in RL 19004r (drawing in the top right-hand corner). The four illustrations by Arfe of the skeleton of the leg and foot in fol. [23]r and fol. [23] v do correspond with Leonardo's sketches of the same subject in RL 19008r. Here, Leonardo exposes the bone structure of the leg and foot from the front, back and sides. 


\section{Models of the third chapter on superficial musculature}

An interesting point is that Arfe's chapter on musculature, entitled morzillos del cuerpo, does not correspond with any didactics and visualisation technique of later literature on artistic anatomy regarding superficial musculature. All other manuals on artistic anatomy of the early seventeenth century, the Anatomie der wtterlicke deelen of 1634 and Abrégé d'anatomie of 1667, contain myological figures directly copied from the Fabrica ${ }^{23}$. Regarding Arfe the two possible sources of the third chapter are again the manual by Valverde and the studies by Leonardo.

In Arfe's book, musculature is stylized to flat areas, as displayed in the posterior aspect of the musculature of the torso in fol. 30v (fig. 7), which corresponds in many aspects with a model drawing by Leonardo in RL 19044r (fig. 6). Arfe's icons of superficial musculature in the rear view of the torso show no resemblance to the common medical anatomical iconography of this time. For instance, Tabla nona of the second book by Valverde shows a rendering of muscles that is different to Arfe's fol. 30v. The icons of musculature by Arfe are similar to drawings of the naked male body. Today, this method of visualisation with a mixture of parts seen on the living model combined with knowledge of the superficial musculature would be called "morphology" 24 . Within the history of artistic anatomy, Arfe's iconography of the musculature represents an exception. He only describes muscles which are seen on the surface of the living model, as is expounded in the third chapter ${ }^{25}$.

Arfe reduced superficial musculature to "bulges" and he visualised parts of the skeleton which could be seen on the living model. He taught a simplified form of myology and combined several muscles into one. He described them as xixiones, which could be translated as "areas". For instance, the torso from behind in fol. 30v (fig. 7) shows an unusual form of the trapezius entitled "D". A similar form is present in Leonardo's rendering of the back in RL 19044r (fig. 6), where the muscles on both sides of the spine are drawn in an extremely exaggerated form. A similar division is displayed in Arfe's picture and even the position of the left arm is mirrored in every detail, such as the position of the deltoid, indicated with a capital "V" (fig. 6). There is little similarity to the plate showing the superficial musculature of the whole body from behind in the Historia by Valverde, where the trapezius is displayed in the modern manner as a triangular flat form and the musculature of the back is not as exaggerated as in the pictures by Leonardo and Arfe. The trapezius is not drawn in the illustrations by Leonardo and Arfe.

Another example of adaption is Leonardo's RL 19032v (fig. 4), with a model drawing of the male torso from the side. This drawing seems to be mirrored in Arfe's fol. 7r (fig. 2). Differences are the changed position of the arm, the exposition of the sternomastoid ("B"), the deltoid ("V") and the thoracic arch from the side view in Arfe's illustration. One similarity is the rendering of the serratus (anterior) ("4", " $5 "$, " 6 "), which is also marked with letters in the drawing by Leonardo. The pectoralis major ("P") and the flank pad ("6") found their equivalent in Leonardo's sketch.

\footnotetext{
${ }^{23}$ Already the Livre de pourtraiture [1595] by Jean Cousin contained figures copied from the Fabrica. Regarding the early books on artistic anatomy in Western and Central Europe, the explanations also had a medical character and were derived from medical books. The first books which presented alternatives to the medical teaching of artistic anatomy were orientated towards model books with statues of Antiquity. Early examples are Anatomia dei pittori (1679) by Carlo Cesio and Anatomia per uso et intelligenza del disegno (1691) by Gernardino Genga and Charles Errard.

24 The morphological method came into use in France in the mid-nineteenth century. The first handbook in which this method was expounded exhaustively was Anatomie des formes extérieurs du corps humain, appliquée à la peinture, à la sculpture e à la chirurgie (1829) by Pierre Nicolas Gerdy.

25 ARfe y Villafane, 1585: Lib. 2, fol. 25v.
}

Arch. esp. arte, LXXXVII, 346, ABRIL-JUNIO 2014, 139-156

ISSN: 0004-0428, eISSN: 1988-8511, doi: 10.3989/aearte.2014.10 


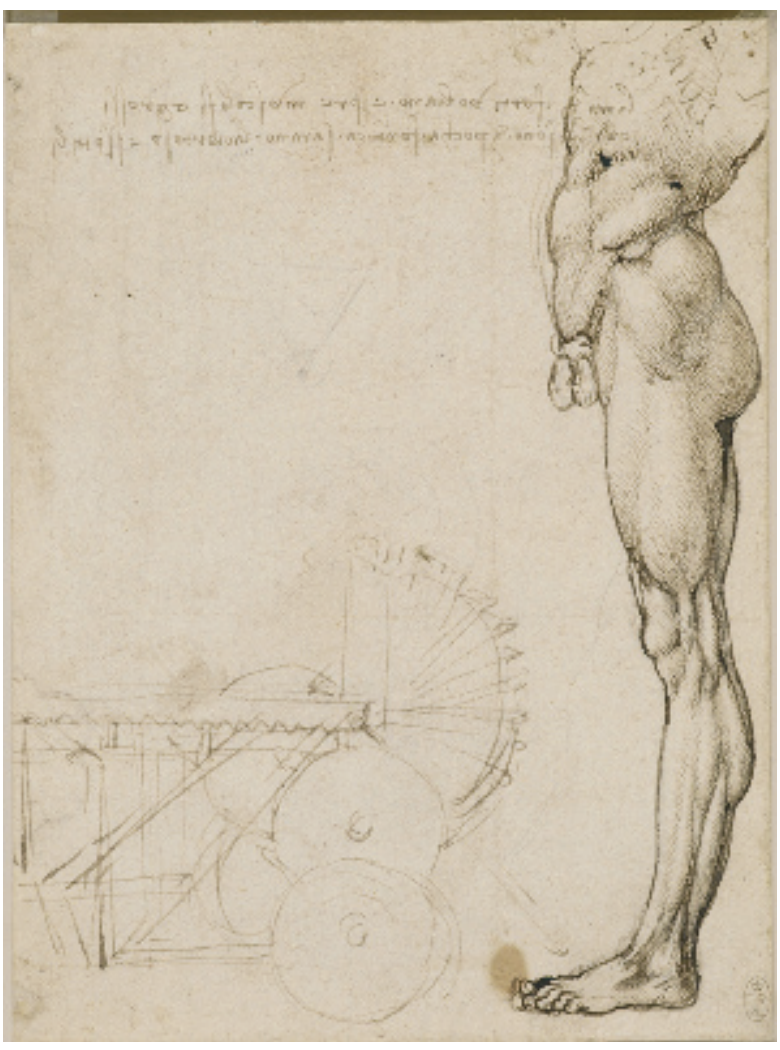

Fig. 8. Leonardo da Vinci, Anatomical study of the musculature of the leg, seen in profile, pen and ink, $19.6 \times 31.3 \mathrm{~cm}$, Windsor Castle, Royal Library, RL 12632r (C) The Royal Collection, HM Queen Elizabeth II.

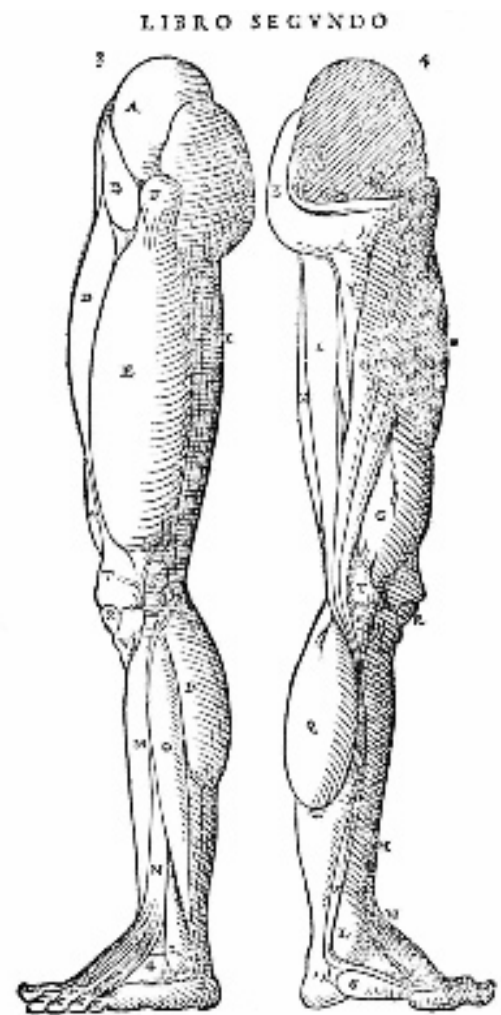

Fig. 9. Juan de Arfe, Superficial musculature of the legs, seen in profile, from Varia commensuración, 1585 , lead print, $27 \times 19.5$ $\mathrm{cm}$, Johann-Wolfgang-Goethe University Library, Frankfurt on Main, Q 15/39.

The comparison between Leonardo's anatomical drawings and the illustrations in the book by Arfe reveals further parallels, for example regarding the pictures of the arm and shoulder musculature. The different muscles of the arm are presented from different views on RL 19005v, RL $19008 \mathrm{r}$ and $19012 \mathrm{v}$. Arfe's illustrations of the upper extremity from the anterior and posterior view and from the inner and outer sides in fols. $33 \mathrm{r}, 33 \mathrm{v}, 34 \mathrm{r}$ and $34 \mathrm{v}$ show certain similarities to these drawings, but there is no direct equivalent.

Regarding the muscles of the lower extremity, possible models are Leonardo's drawings as well as illustrations in the manual by Valverde. For example, the model of Arfe's fol. 36r (musculature of the leg seen from behind) might have been the right foot of the male figure of Tabla nona in the second book by Valverde.

There are different reasons why Leonardo's and Valverde's images did not appear exactly in their original views. The first reason is that Arfe's explanations regarding the skeleton and the musculature are changed and simplified extracts of the Historia by Valverde ${ }^{26}$. Therefore, he had

26 CORTES, 1994: 164-204. 
to change the pictorial patterns according to these explanations. Another reason might have been the printing technique of the Varia. It was difficult to transfer the fine hatchings and many details of the drawings onto printing plates. Arfe had to change the original images.

A further consideration to explain why not all of Arfe's illustrations found a counterpart in Leonardo's anatomical drawings is simply the general structure of Libro segundo. All views were already fixed in the first subchapter on proportions, since the subsequent subchapters on the skeleton and the musculature show exactly the same views of limbs. Not all of these views are contained in Leonardo's study sheets, for he displayed the anatomy of the human body in a less rigorous system of ordering. Therefore, Arfe either had to invent several illustrations or change illustrations from the book by Valverde. By doing this, he worked in the same manner as early illustrators of books on botany in the fifteenth century. In natural sciences, the illustrator does not invent something new. His work is aimed at knowing and modifying older pictorial material and integrating new important details according to new scientific discoveries or new techniques of representation.

\section{The path of transmission of Leonardo's studies}

If we assume that Arfe used Leonardo drawings as model for the first, second and third chapters of Libro segundo the question arises as to how could Arfe study the sketches by Leonardo. There are two possible ways:

1. A transmission via Spanish artists who were acquainted with Italian art techniques und who were friends of Arfe.

2. A transmission via the Pompeo Leoni-Volume, a compilation of drawings by Leonardo.

In specialised Spanish art literature the opinion is stressed that there had been strong native traditions of anatomical drawings, especially by Alonso Berruguete and Gaspar Becerra ${ }^{27}$. Both studied anatomical drawing in Italy and both were acquainted with the Italian art techniques. Both lived in Valladolid. Berruguete had his workshop near those of the Arfe family. Furthermore, Arfe was a friend of Becerra, who had been an artist in the service of Giorgio Vasari. He and his friend, the painter Pedro Rubiales, are said to have been among those artists who created the splendid illustrations of Valverde's Historia de la composicion del cuerpo humano of 1556. Spanish art historical literature places strong emphasis on the fact that Becerra had been the creator of some illustrations ${ }^{28}$. Nevertheless, this argument is not supported by a passage in the manual of Valverde, in which only Michelangelo and Rubiales are mentioned as having combined anatomy and painting. The two men are not indicated as creators of the illustrations ${ }^{29}$. Therefore, in Spanish scientific literature on medical history, the question as to whether Becerra had been the creator of some of the illustrations is left unanswered, even if this does seem to be possible ${ }^{30}$. If Spanish artists were involved in creating illustrations of a manual on medical anatomy, how could they transfer their knowledge to Spain? It is not confirmed that Rubiales has something to do with the illustrations of Libro segundo, as a recent study suggests ${ }^{31}$. Another possible source could be the model drawings by Becerra which he had taken in a chest from Italy to Valladolid ${ }^{32}$. Some anatomical drawings of the sixteenth century stored in Spanish archives are attributed to

\footnotetext{
27 Regarding the following passage I would like to thank Prof. em. Carmen Heredia Moreno for her advice.

28 Capel Margarito, 1998: 21; Cortes, 1994: 145.

29 RIERA, 1981: 42.

30 RIERA, 1981: 42-45.

31 Heredia Moreno, 2005, De Arte: 63-74.

32 Heredia Moreno, 2005, El arte foráneo: 309.
}

Arch. esp. arte, LXXXVII, 346, ABRIL-JUNIO 2014, 139-156

ISSN: 0004-0428, eISSN: 1988-8511, doi: 10.3989/aearte.2014.10 


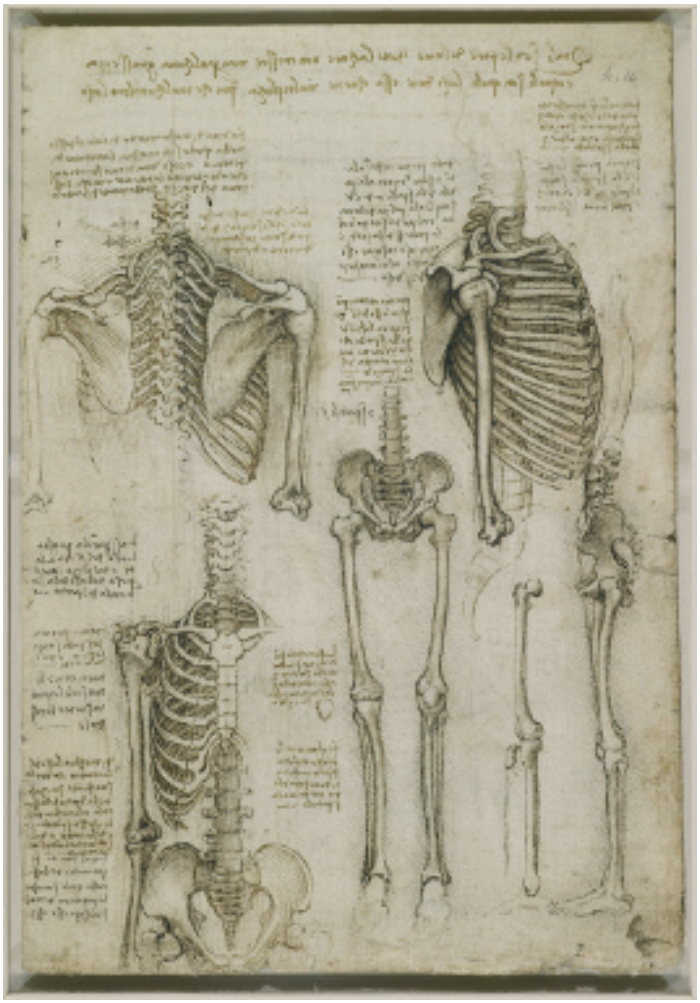

Fig. 10. Leonardo da Vinci, The skeleton of the trunk and legs, pen and ink, $28.8 \times 20 \mathrm{~cm}$, Windsor Castle, Royal Library, RL 19012r (C) The Royal Collection, HM Queen Elizabeth II.

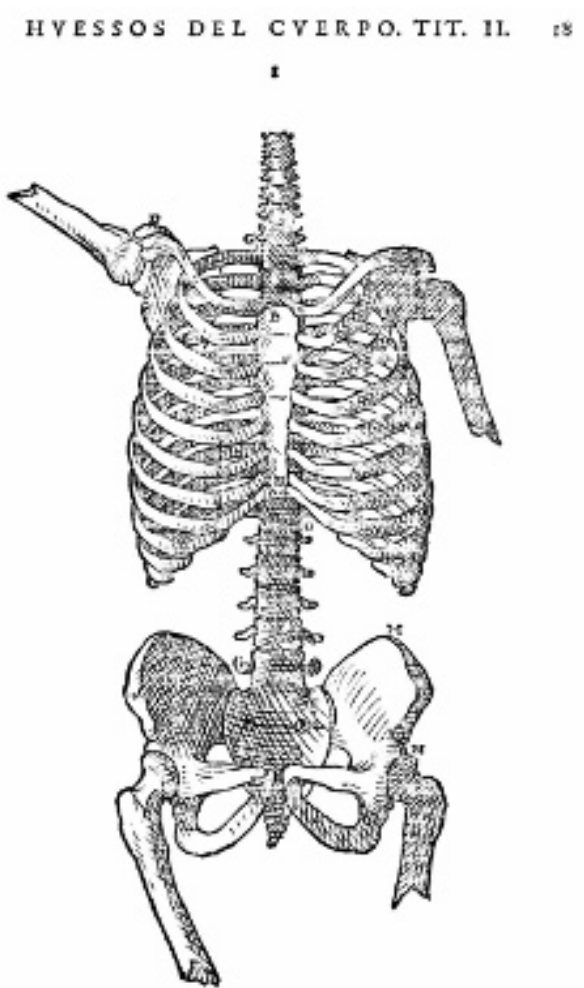

Fig. 11. Juan de Arfe, Skeleton of the trunk, seen from in front, from Varia commensuración, 1585, lead print, $27 \times 19.5 \mathrm{~cm}$, Johann-Wolfgang-Goethe University Library, Frankfurt on Main, Q 15/39.

Becerra $^{33}$. Yet, these drawings show no similarities to the illustrations of Libro segundo. Spanish artists who had knowledge of Italian art techniques transferred anatomical rendering to Valladolid. Arfe was introduced to this subject through them. We must remember that Arfe mentions Berruguete as well as Becerra in Libro segundo.

Another "channel" is the spreading of Leonardo drawings via the so-called Pompeo Leonivolume in Madrid. The scare certain information about this volume is as follows: after the death of Francesco Melzi (heir of the Leonardo legacy) in the year 1570, his collection of Leonardo's drawings and writings passed through different hands, but finally the sculptor Pompeo Leoni from Milan purchased large parts of this collection. The exact time of this is not known, but it was between 1582-1589 during a stay in Italy ${ }^{34}$. Since he was an art merchant and collector, he tried to sell the drawings in Spain. In all probability, he tried to offer them to Philipp II. However, we do not know much about the fate of the collection that was stored in Pompeo's house

33 Capel Margarito, 1998: 30-37.

34 Neumann, 1997: 50-52. Sometimes the time around 1590 is mentioned. However, this date is based on a remark by Lomazzo in the year 1590 that he "heard" that the manuscripts had been sold. He did not mention the exact time. See: Clark, 1968: vol. 1, [p.] X. 
in Madrid. Nevertheless, the few things that we do know lead directly to Libro segundo. The first thing that we know for sure is that Pompeo changed the sheets by Leonardo in his possession. For instance, he cut out pieces of Leonardo's caricatures and glued them on different papers, cut larger drawings into smaller formats and so on. The second, more important fact is that artists could study the drawings by Leonardo during the lifetime of Pompeo Leoni in his house in Madrid. During his travel to Spain in the year 1603, Peter Paul Rubens was able to see Leonardo's anatomical drawings in the possession of Leoni. This is indicated in the Abrégé de la vie des peintres (1715) by Roger de Piles ${ }^{35}$.

The problem that arises is that: the first documented co-operation between Arfe and Leoni was in the year $1596^{36}$. However, Libro segundo was printed in 1585 and there is no written testimony that the two men had met each other before 1596. In light of this, if anatomical drawings by Leonardo had been in Madrid before 1585, how could Arfe have used them as models?

The key to understanding the spread of anatomical knowledge among sixteenth-century artists in Southern Europe are Italian anatomical sketchbooks, such as the Bandinelli album (British Museum) and the convolute of anatomical drawings entitled Siena MS.S.II.5, which was studied by the author of this article in the Biblioteca Comunale degli Intronati in Siena. The volume Siena MS.S.II.5 is composed of drawings from different anonymous artists of the sixteenth century. It contains a mixture of drawings of the nude model and anatomical model drawings of the superficial musculature without any written explanations. These drawings were created in various workshops by different artists, and were used as models for beginners as well as advanced artists. Many of them were destroyed through the process of being copied by training draftsmen. Decades later, the most beautiful of these collections of sheets were purchased by an art collector and bound together into a volume. The many Italian anatomical model drawings of the sixteenth century represent the "missing link" between the first anatomical drawings and the printed book illustrations of the seventeenth century. The compilation Siena MS.S.II.5 (which is still in the original state of a typical sixteenth-century Italian anatomical model collection) shows a strong relationship to the character of the Pompeo Leone-Volume. We do not know how many Leonardo drawings were in the possession of Pompeo Leoni when he returned to Spain in the 1580s. Furthermore, we do not know when these sheets were bound together into a volume. The first certain information we have about the existence of the Pompeo Leoni-Volume, which contained 234 leaves, is an inventory made on July 15 th $1613^{37}$.

So, if we know the practice of learning in the sixteenth century, it is not surprising that we have anatomical drawings related to the Pompeo Leoni-Volume in different museums and libraries on the European continent. One of these drawings, which is believed to be a copy, is in the Ambrosiana in Milan (fig. 12) and has the inventory number F 263 inf. 84. It is obviously a copy of sheets from the Pompeo Leoni-Volume, now known as RL 12632r (fig. 8) and RL 12633v ${ }^{38}$. The study of legs in the Ambrosiana is also related to RL 12625r, one of the most beautiful sheets, which could represent the original model. Similar drawings are those in Codice sul volo and Codice Atlantico. Moreover, the drawing of the lower extremity of a man is repeated several times in the Pompeo Leoni-Volume, such as RL 12634r, RL 12633r, RL 19036r and RL 19036v, in addition to many other drawings. We have proof that different sheets by Leonardo were copied

\footnotetext{
35 Piles, 1715: 162: "Rubens s'étend ensuite sur le dégré auquel Leonard de Vinci possedoit l'Anatomie. Il rapporte en detail toutes les Etudes et tous les Etudes \& tous les Desseins que Leonard avoit faits, \& que Rubens avoit vûs parmi les curiositéz d'un nommé Pompée Leoni, que étoit d'Arezzo".

36 Heredia Moreno, 2005, El arte foráneo: 317-318. On the collaboration between Arfe and Leoni see: NieveS Alonso FernÁndeZ, 1940.

37 Clark, 1968: vol. 1, [p.] X; Sanchez Esteban, 1995: 108.

38 MARANI, 1998: 76-77.
}

Arch. esp. arte, LXXXVII, 346, ABRIL-JUNIO 2014, 139-156

ISSN: 0004-0428, eISSN: 1988-8511, doi: 10.3989/aearte.2014.10 


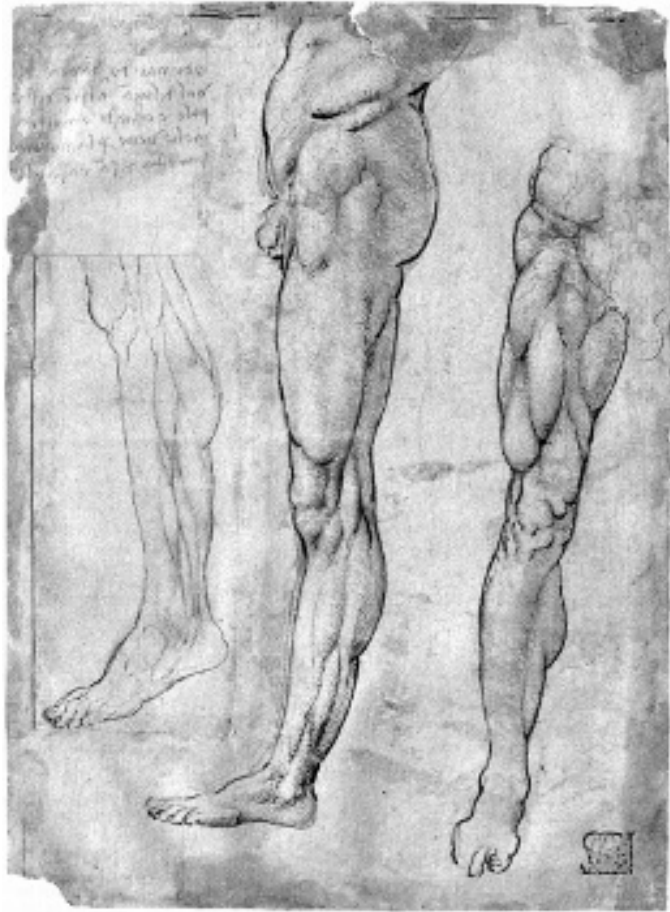

Fig. 12. Anonymous artist, Anatomical studies of the musculature of the leg, red chalk, pen and ink drawing, $20.2 \times 14.8 \mathrm{~cm}$, Ambrosiana, Milan, F 263 inf. 84. by different anonymous artists with the aim of gaining knowledge in anatomical drawing.

Regarded from this point of view, it is not surprising that Leonardo's splendid proportion study of a head (fig. 5) is stored in five versions in different European museums. We must remember that precisely this image could have served as patterns for Arfe's proportion heads [4]v (fig. 3). Thus, we have the second image of Libro segundo, where we have not only one but many different copies of original Leonardo drawings, which could have been the source of Arfe's illustration of the head.

If we suppose that there had been a far larger number of copies of Leonardo drawings during the sixteenth century, it is no wonder that RL 12632r or similar copies could have been the model of Arfe's page 36v (fig. 9). It is a fact that Pompeo Leoni allowed artists to make copies of Leonardo's anatomical drawings, and this had been a practice since Melzi inherited Leonardo's drawings. Even if it is unlikely that Arfe and Leoni had met each other before the 1590s, we can be sure that Arfe, who was interested in anatomy, did know various anatomical model drawings which circulated in Southern Europe. There were other Spanish artists, such as Juan Bautista de Monegro, who had knowledge of Leonardo's manuscripts ${ }^{39}$.

Some illustrations of the first and third chapters of Libro segundo are based on than well-known didactical drawings attributed to Leonardo: in two cases, fol. [4]v (fig. 3) and fol. $36 \mathrm{v}$ (fig. 9), we even have the proof that there were at least four or more copies which are still stored in European collections; the original number of these copies which circulated all over the Roman countries must have been higher.

If Arfe had used copies of Leonardo's drawings, why did he not mention him in the Varia? He must have known his name. Arfe was in the possession of a copy of the Vite by Vasari ${ }^{40}$. There might be many reasons for this. In the age of Counter-Reformation, Leonardo had a certain dubious reputation. This is mirrored in his biography by Vasari who described him as a very strange person. In addition, a passage of the first edition of the Vite (which was deleted in the second edition) reads: He had a spirit which was heretically disposed, so he wasn't an adherent of any religion and he believed that it would be better to be a philosopher than a Christian ${ }^{41}$. Leonardo's

39 This is indicated by a hand written notice by the sculptor Monegro in the book De Divina Proportione (1509) by Luca Pacioli: I seguenti corpi sono di Leonardo da Vinci. Disegna H. fo 301 cap. X parte prima. MARÍAs, 1981 : 96-97.

40 Heredia Moreno, 1995, El arte foráneo: 308, note 7.

41 Per il che fece ne l'animo un concetto si eretico, che e' non se accostava a qualsivoglia religione, stimando per avventura assai più lo esser filosofo che cristiano. VASARI, 1550 (ED. OF 1976): vol. 4, 19.

Arch. esp. arte, LXXXVII, 346, ABRIL-JUNIO 2014, 139-156 ISSN: 0004-0428, eISSN: 1988-8511, doi: 10.3989/aearte.2014.10 
work was admired amongst certain circles, but he was known as a freethinker, as a draftsman of "secret things" and the naked body. However, it is improbable that this might be reason that his name did not appear in Libro segundo.

A second hypothesis is more likely. It is a fact that Arfe consciously failed to indicate very important sources of his Libro segundo. For instance, he did not mention the fact that the text of Libro segundo regarding the skeleton and the musculature had been derived from the Historia by Valverde ${ }^{42}$. Perhaps Arfe wanted to reap all the fame for creating the most important Spanish manual on drawing the human figure for himself. The whole text of the Varia suggests that Arfe saw himself as the creator of a new sort of teaching manual, the one who took Spanish art and the reputation of artists on a higher intellectual level - and, indeed, that was true.

The images of Libro segundo are compiled from three sources: Dürer's Vier Bücher, Valverde's Historia and well-known anatomical drawings by Leonardo or copies of these drawings. The general idea of showing all parts of the body exactly from four views seems to be grounded in the anatomical studies by Leonardo and the Vier Bücher by Dürer. Leonardo and Dürer are the main sources of the images in the subchapter on proportions. The illustrations of the subchapter on foreshortenings are mainly copied from the Vier Bücher by Dürer. Regarding the subchapters on osteology and myology the models are the studies by Leonardo and the Historia by Valverde. The subdivision of the human body in different segments is the same as in some anatomical studies by Leonardo.

Arfe conceived a division of the body into four parts: the head, torso, arm and hand, and leg and foot. Each of these four parts is similar to architectural drawing, displayed exactly from all four sides. Such a rigid division could not be found in any other anatomy book of the sixteenth century. Arfe could not have conceived such a complex presentation of anatomy without any precursory model. The only models available in the late sixteenth century in which such a presentation of the body was shown were the studies by Leonardo. It was the genius of the Spanish artist Arfe y Villafañe that conceived a new and logically structured manual on drawing the human figure, compiled from older pictorial material. Libro segundo of the Varia is a pivotal contribution to European art didactical literature.

\title{
Appendix
}

Illustrations of the Varia commensuración and analogies in the Windor convolute of anatomical drawings by Leonardo da Vinci, in the Four Books by Dürer and in Historia by Valverde

\author{
Abbreviations: \\ Position of illustration or drawing on the sheet \\ [u. p.] = upper part of the sheet/page \\ [1. p. $]=$ lower part of the sheet/page \\ [1. s.] = left side \\ [r. s.] = right side \\ Description of anatomical aspect presented on the sheet \\ i. $\mathrm{fr} .=$ in front/anterior aspect \\ f. $\mathrm{b} .=$ from behind/posterior aspect
}

42 CORTES 1994: 164-180 (regarding the skeleton), 180-204 (regarding the musculature).

Arch. esp. arte, LXXXVII, 346, ABRIL-JUNIO 2014, 139-156

ISSN: 0004-0428, eISSN: 1988-8511, doi: 10.3989/aearte.2014.10 
pr. $1 .=$ profile to the left

pr. $\mathrm{r}$. $=$ profile to the right

o. $\mathrm{s} .=$ seen from the outer side

i. $\mathrm{s}$. $=$ seen from the inner side

prop. $=$ proportions $\quad$ skel. $=$ skeleton $\quad$ musc. $=$ superficial musculature $/$ surface of the body

Varia commensuración

Analogies

\section{Proportions}

fol. [4]r, prop. of the face, i. fr.

fol. [4]r, prop. of the face, f. b.

fol. [4]v [u. p.], prop. of the face, pr. 1.

fol. [4]v [1. p.], prop. of the face, pr. r.

fol. $6 r$, prop. of the torso, i. fr.

fol. $6 \mathrm{v}$, prop. of the torso, f. b.

fol. $7 \mathrm{r}$, prop. of the torso, pr. 1 .

fol. $7 \mathrm{v}$, prop. of the torso, pr. $\mathrm{r}$

fol. $7 \mathrm{r}=$ mirror image of $7 \mathrm{v}$

fol. 9 r [1. s.], prop. of upper extremity. i. fr. fol. $9 \mathrm{r}$ [r. s.], prop. of upper extremity, f. b. fol. $9 \mathrm{v}$ [1. s.], prop. of upper extremity, o. s. fol. $9 \mathrm{v}$ [1. s.], prop. of upper extremity, i. s.

fol. 11r [1. s.], prop. of lower extremity, i. fr. fol. $11 \mathrm{r}$ [r. s.], prop. of lower extremity, f. b.

fol. $11 \mathrm{v}$ [1. s.], prop. of lower extremity, o. s. fol. $11 \mathrm{v}$ [r. s.], prop. of lower extremity, i. s. fol. $13 r$, prop. of the whole body, i. fr. fol. $13 \mathrm{v}$, prop. of the whole body, f. b.
Dürer: Book 2, fol. G5r (head)

Dürer: Book 2, fol. G5v (head)

Leonardo: RL 12601 [similarities also to Dürer]

Leonardo: RL 12601 [similarities also to Dürer]

Leonardo: RL 19032r

Leonardo: RL 19044r

Leonardo: RL 19032v

Leonardo: RL $19032 \mathrm{v}$

[Arfe's fol. $7 \mathrm{r}=$ mirror image of $7 \mathrm{v}$ ]

Dürer: Book 1, fol. B4r (right figure)

Dürer: Book 1, fol. B4r (middle)

$-$

Dürer: Book 1, fol. B4r (right figure)

Leonardo: RL 19036r

[r. s.; Arfe's icon $=$ mirror image]

Leonardo: RL 12632r \& RL 12634

Leonardo: RL 19036v [r. s.], RL 12633r [middle]

Dürer: Book 2, fol. G5r

Dürer: Book 2, fol. G5v

\section{Skeleton}

fols. $15 \mathrm{v}$, skull, i. fr. \& f. b.; fols. 16 r skull, pr. 1. \& r.fol. 18 r, skel. of torso, i. fr.

Leonardo: RL 19012r [1. p.]?

fol. $18 \mathrm{v}$, skel. of torso, f. b.

fol. 19r, skel. of torso, pr. 1 .

[Thorax shows similarities to schemes in Leonardo RL 19044v]

fol. $19 \mathrm{v}$, skel. of torso, pr. r.

[see Leonardo: RL 19044v]

fol. [21]r, skel. of upper extremity, i. fr.

fol. [21] r, skel. of upper extremity, f. b.

fol. [21]v, skel. of upper extremity, o. s.

fol. [21]r, skel. of upper extremity, i. s.

Leonardo: RL 19004r [u. p.; r. s.]?

fol. 23 r, skel. of lower extremity, i. fr.

Leonardo: RL 19008r [u. p.; 2n illustr. from 1. s.]

Valverde: Tab. 1, Lib. 1 [left foot of the skeleton]

fol. $23 \mathrm{v}$, skel. of lower extremity, f. b.

Leonardo: RL 19008r [u. p.; middle]

fol. 23r, skel. of lower extremity, o. s.

Arch. esp. arte, LXXXVII, 346, ABRIL-JUNIO 2014, 139-156 ISSN: 0004-0428, eISSN: 1988-8511, doi: 10.3989/aearte.2014.10 
Varia commensuración

fol. 23r, skel. of lower extremity, i. s.

\section{Superficial musculature / Surface of the body}

fol. $27 \mathrm{r}$ [u. p.], musc. of the face, i. fr.

fol. $27 \mathrm{r}$ [1. p.], musc. of the face, f. $b$.

fol. $27 \mathrm{v}$ [u. p.], musc. of the face, pr. 1.

fol. $27 \mathrm{v}$ [1. p.], face of a bearded man

fol. 30r, musc. of the torso, i. fr.

fol. $30 \mathrm{v}$. musc. of the torso, f. b.

fol. $31 \mathrm{r}$, musc. of the torso, pr. 1.

fol. $31 \mathrm{v}$, musc. of the torso, pr. $\mathrm{r}$.

fol. $33 \mathrm{v}$ [1. s.], musc. of upper extremity, i. fr. fol. $33 \mathrm{v}$ [r. s.], musc. of upper extremity, f. b. fol. $34 \mathrm{r}$ [1. s.], musc. of upper extremity, o. s. fol. $34 \mathrm{r}$ [r. s.], musc. of upper extremity, i. s.

fol. 36r [1. s.], musc. of lower extremity, i. fr.

fol. 36r [r. s.], musc. of lower extremity, f. b.

fol. $36 \mathrm{v}$ [1. s.], musc. of lower extremity, o. s.

fol. 36v [r. s.], musc. of lower extremity, i. s.

\section{Foreshortenings}

fol. $42 \mathrm{v}$, measurement of the whole figure fol. $44 \mathrm{r}$, proportions of the head and other parts of the body

fol. $44 \mathrm{v}$, foreshortenings of a head, i. fr. fol. 45 r, foreshortenings of a head, pr. $r$. fol. $45 \mathrm{r}$, foreshortenings of a woman's head fol. 46r, foreshortenings of a woman's head fol. $46 \mathrm{v}$, foreshortenings of arms
Analogies

Leonardo: RL 19008r [u. p.; 2nd illstr. from r. s.] [position of patella $\&$ arch of the inner (tibial) side of the skel. of the foot modified]

$-$

Leonardo: RL 12579r

[1. s.] [resemblance could be coincidental]

Leonardo: RL 19032r

Valverde: Tab. 3, Lib. 2 [especially musc. of pelvis region]

Leonardo: RL 19044r, RL 19043v

Leonardo: RL 19032v, RL 19014v [mirror image]

Leonardo: RL 19032v

Valverde: Tab. 2, Lib. 2

[Regarding the upper extremities it is difficult to specify a concrete source, since the musculature of the arm is partly erroneously depicted in the Varia commensuración. Possible sources are: Leonardo: RL 19005v, RL 19008r; 19012v [1. s. \& r. s.]]

Similarities to several sheets, such as Leonardo: RL 19014r [left leg], 19014v [middle], possible: RL $12633 \mathrm{v}$, RL $12631 \mathrm{r}$

Valverde: Tab. 3, Lib. 2 [left foot]

Leonardo: RL 19036r [r. s.; Arfe's icon = mirror image]

Valverde: Tab. 9, Lib. 2 [right foot]

Leonardo: RL 12632r; 12634r; possible: RL $12625 \mathrm{r}$ [1. p.,. 1. s.],

Leonardo: RL 19014r [r. s.] [mirror image]; Valverde: Tab. 2, Lib. 2

Leonardo: RL 19036v [r. s.], RL 12633r [middle], RL 19010r [foot]

Valverde: Tab 2, Lib. 2; Tab. 15, Lib. 2 [left side]

Dürer: Book 4, fol. Y3v

Dürer: Book 1, fol. F1r, Dürer: Book 4, fol. Y4r

Dürer: Book 4, fol. V3v

Dürer: Book 4, fol. V4r

$-$

Dürer: Book 4, fol. V4v

Dürer: Book 4, fol. X1v

Arch. esp. arte, LXXXVII, 346, ABRIL-JUNIO 2014, 139-156

ISSN: 0004-0428, eISSN: 1988-8511, doi: 10.3989/aearte.2014.10 


\section{BIBLIOGRAPHY}

Arfe y Villafañe, Juan, De varia commensvración para la Escvlptvra y Architectura, Sevilla, Andrea Pescioni y Juan de Leon, 1585, 1587, 4 vols.

Capel Margarito, Manuel, Gaspar Becerra o el miguelangelismo español, Jaen 1998.

Clark, Kenneth and Pedretti, Carlo, The Drawings of Leonardo da Vinci in the Collection of Her Majesty the Queen at Windsor Castle, London, Phaidon Press, 1968, vol. 1.

Cortés, Valerià, Anatomía, academia y dibujo clásico, Madrid, Catedra 1994.

Cousin (jeune), Jean, Livre de pourtraiture [...]. Contenant par une facile instruction, plusieurs plans et figures de toutes les parties séparées du corps humain [...], Paris, J[ean] Le Clerc [1595].

Crespo Fajardo, "Dibujos y copias manuscritas de la Varia Commensuracion de Juan de Arfe. Nuevos aportes documentales", in Estudios de plantería, Murcia, Universidad de Murcia 2001, pp. 161-171.

Dürer, Albrecht, HJerin[ $n$ ] sind begriffen vier bücher von menschlicher Proportion [...], Nürnberg, Jeronymus Fromschneyder, 1528.

García López, David, "Lectores y observatores. La fortuna de los libros de Juan de Arfe [...]”, in Estudios de planteria, Murcia, Universidad de Murcia 2001, pp. 247-264.

Gauricus, Pomponius, De Sculptura vbi agitur de Symetriis. De Lineamentis. De Physiognomia [...], Florence, Philipp Giunta, 1503.

Heredia Moreno, Carmen, "Juan de Arfe y Sebastiano Serlio", in Archivo Español de Arte, 76 (2003), no. 304, pp. 371-388.

Heredia Moreno, Carmen, "Sombre las fuentes europeas de Juan de Arfe y Villafañe”, in Cabañas Bravo, Miguel (ed.), El arte foráneo en España, Madrid, Departamento de Historia del Arte, Instituto de Historia, Consejo Superior de Investigaciones Científicas 2005, pp. 307-318.

Heredia Moreno, Carmen, "Algunas cuestiones pendientes sobre las estampas de la Varia Commensuracion de Juan de Arfe y un posible inédito de Pedro Rubiales”, in De Arte, Revista del historia del arte, Universidad de León, 4 (2005), pp. 63-71.

Hinz, Berthold (ed.), Albrecht Dürer. Vier Bücher von menschlicher Proportion (1528), Berlin, Akademie Verlag, 2011.

Kornell, Monique, Artists and the Study of Anatomy in Sixteenth-Century Italy, unpubl. PhD diss., Warburg Institute, University of London, 1993, 2 vols.

Marani, Pietro C. et al., L'Ambrosiana e Leonardo, Novarra, Interlinea edizioni, 1998.

Marías, Fernando, "Juan Bautista de Monegro, su biblioteca y 'De Divina proporcione", in Academia, Madrid, 53 (1981), pp. 89-117.

Neumann, Mechthild, Pompeo Leoni - um 1530-1608: ein italienischer Bildhauer am Hofe Philipps II. von Spanien, Ph.D. diss., Bonn, Rheinische-Friedrich-Wilhelms-Universität, 1997.

Nieves Alonso Fernández, María de las, “Juan de Arfe y Pompeo Leoni”, in Boletín del Seminario de Estudios de Arte y Arqueología, Consejo Superior de Investigaciones Científicas, Universidad de Valladolid, 7 (1940), pp. [171]-85, [plates I-III on pp. 61-63].

Piles, Roger de, Abrégé de la vie des peintres [...], Paris, Jacques Estienne, 1715.

Riera, Juan, Valverde y la anatomia del Renacimiento, Valladolid, Universidad de Valladolid 1981.

Röhrl, Boris, History and Bibliography of Artistic Anatomy, Hildesheim, New York, Olms 2000.

Röhrl, Boris, Geschichte und Bibliographie der Tierzeichenbücher 1528-2008. History and Bibliography of Books on Animal Drawing, Stuttgart: Hiersemann 2009, pp. 130-132.

Sánchez Esteban, Natividad, "El legado de Pompeo Leoni: su biblioteca y los manuscritos de Leonardo", in Gatti Perer, Maria Luisa (ed.), Leone Leoni tra Lombardia e Spagna. Atti di convegno internazionale [...], Milan, Istituto per la Storia dell'Arte Lombarda, 1995, pp. 105-112 (especially p. 108, Apéndice).

Vasari, Giorgio, Le vite [...] nelle redazioni del 1550 e 1568, Firenze 1976, tomo IV.

Valverde di Hamusco, Juan, Historia de la composición del cuerpo humano [...], Rome, Antonio Salamanca y Antonio Lafrerij, 1556.

Vesalius, Andreas, De humani corporis fabrica libri septem, Basle, Joannis Oporini, 1543.

Fecha de recepción: 10-XII-2012

Fecha de aceptación: 11-IX-2013

Arch. esp. arte, LXXXVII, 346, ABRIL-JUNIO 2014, 139-156

ISSN: 0004-0428, eISSN: 1988-8511, doi: 10.3989/aearte.2014.10 